$\mathrm{A} \mathrm{J}_{\mathrm{ass}} \mathrm{H}$

Article history :

Received : 27.03.2018

Revised : 06.05.2018

Accepted : 20.05.2018
Members of the Research Forum

Associated Authors:

${ }^{1}$ Department of Conservation Biology, Durgapur Government

College, Durgapur, Paschim

Bardhaman (W.B.) India

Email: ka.debalina@gmail.com

${ }^{2}$ Department of Botany, Burdwan University, Burdwan, Purba

Bardhaman (W.B.) India

Email: amukherjee@bot.buruniv.ac.in

Author for correspondence :

Debnath Palit

Department of Botany, Durgapur

Government College, Durgapur,

Paschim Bardhaman (W.B.) India

Email: debnath_palit@yahoo.com
THEASIAN JOURNALOF HORTICULTURE

Volume 13 | Issue 1 | June, 2018 | 8-13

Visit us -www.researchjournal.co.in
RESEARCH PAPER

DOI : 10.15740/HAS/TAJH/13.1/8-13

\section{Flowering and fruiting responses of the wetland macrophytes in Birbhum district, West Bengal, India}

\section{Debnath Palit, Debalina Kar ${ }^{1}$ and Ambarish Mukherjee ${ }^{2}$}

ABSTRACT : The present investigation is an outcome of the flowering and fruiting responses of 182 angiospermic species occurring in wetlands of Birbhum district. Seven seasonal categories of flowering and fruiting responses and high number of species spreading their flowering and fruiting throughout the year were observed. This indicates temporal segregation of reproductive phases to avoid competitive exclusion.

KEY WORDS : Flowering, Fruiting responses, Angiospermic species, Wetlands, Phenological spread, Reproductive biology, Temporal segregation

HOW TO CITE THIS ARTICLE : Palit, Debnath, Kar, Debalina and Mukherjee, Ambarish (2018). Flowering and fruiting responses of the wetland macrophytes in Birbhum district, West Bengal, India. Asian J. Hort., 13(1) : 8-13, DOI : 10.15740/HAS/TAJH/13.1/8-13. 